\title{
Góry czeskie i słowackie jako element narodowego mitu
}

\section{https://doi.org/10.19195/2084-4107.15.11}

Vladimír Macura w kanonicznej już książce Znamení zrodu. České národni obrozeni jako kulturni typ (wyd. 1 - 1983, wyd. 2 - 1995) przeanalizował podstawowe zasady będące konstrukcyjną osnową czeskiej kultury dziewiętnastowiecznej. Były to językocentryzm (to jest — koncentracja na języku jako wartości bezwzględnej), tłumaczenia dzieł obcej literatury, mitologizacja i mistyfikacja. Każda z tych zasad reprezentuje osobny rozdział dotyczący narodzin nowoczesnej kultury czeskiej; natomiast dla tu podjętego badania fundamentalne znaczenie ma problem mitologizacji, co — według Macury — tłumaczy zarówno obecność pewnych elementów mitologicznych w kulturze odrodzenia narodowego, jak i bardzo bliski związek między kulturą a mitem ${ }^{1}$. Według Macury narodziny współczesnej kultury czeskiej były narodzinami wielkiego mitu, który ma swój eschatologiczny poziom (patrz wciąż powszechna metafora zmartwychwstania zmarłego lub przynajmniej śpiącego narodu) i jest niesiony przez znaczną kreatywność twórczą tych, którzy ten mit kultywują i przekształcają. W ujęciu Macury zasada mitologizacji miała szeroki zakres i prócz — co chyba nie dziwi — zjawisk historycznych ${ }^{2}$, ogarnęła także na przykład „fakty geograficzne”, którym poświęcono „ważne miejsca w topografii czeskiej i słowiańskiej”3. Według Macury najbardziej produktywnymi elementami topograficznymi „mitycznego dyskursu" kultury czeskiej były Praga, Wyszehrad, Wełtawa, ruiny skalne Trosky, a także Karkonosze i Tatry ${ }^{4}$. W innym miejscu Macura wspomina również wzgórza Říp i Blaník, które w przeciwieństwie do Karkonoszy i Tatr odgrywały istotną rolę w czeskiej mitologii już od wczesnego średniowiecza ${ }^{5}$. Dziś Karkonosze i Tatry są ważnymi formacjami geologicznymi na terenie dwóch niezależnych państw, Republiki Czeskiej i Słowackiej, i często bez wahania mówimy o nich jako o najwyższym masywie górskim Czech i Słowacji. W pierwszej połowie XIX wieku, kiedy narodziły się nowoczesna kultura czeska i słowacka, ta jednoznaczność tej narodowej identyfikacji nie była jednak oczywista. Oba

1 V. Macura, Znamení zrodu: české národní obrození jako kulturni typ, Praha 1995, s. 79.

2 Mitologizowane były nie tylko historyczne wydarzenia, ale także wybitne postaci. Szczególnie produktywny pod tym względem był okres husycki, ale także bitwa pod Białą Górą. Spośród postaci na wymienienie zasługują Jan Hus, Jan Žižka, a także niektórzy czescy królowie. Zob. np. V. Macura, Český sen, Praha 1998; J. Rak, Bývali Čechové... České historické mýty a stereotypy, Jinočany 1994; P. Čornej, Husitství a husité, Praha 2019.

3 Ibidem, s. 81.

4 Ibidem.

${ }^{5} \mathrm{O}$ tym np. D. Třeštík, Mýty kmene Čechi̊: (7.-10. století): tři studie ke starým pověstem českým, Praha 2003, s. 73-76. 
pasma górskie leżały na terytorium monarchii austriackiej, obecny zaś w nich element etniczny był nie tylko czeski i słowacki, ale także niemiecki, polski i węgierski. Działalność kulturalna, a zwłaszcza twórczość literacka, odegrały tu zatem kluczową rolę: to one zaczęły stawiać określone wymagania wobec danej przestrzeni i starały się doprecyzować jej czeski, ewentualnie słowacki, charakter i pochodzenie. W kontekście emancypacji kultury czeskiej i słowackiej powszechną praktyką było głoszenie identyfikacji narodowego charakteru gór, co wiązało się z aspektem ich zaludnienia: góry można było uznać za znaczną część terytorium zamieszkanego przez Słowian. W pracy Vladimíra Macury przeanalizowano narodowy mitologiczny potencjał gór, zwłaszcza w odniesieniu do Tatr. Karkonosze pojawiają się tu sporadycznie, a ogólnie wydaje się, że czeski badacz przypisuje Tatrom pewnego rodzaju dominację literacką nad górami czeskimi. W swoich interpretacjach zwraca szczególną uwagę na stopniową krystalizację obrazu Tatr jako ekskluzywnej przestrzeni ojczyzny, czyli w szerszym znaczeniu — słowiańskiej. W jego przekonaniu idea ta rozprzestrzeniła się w kontekście czeskim za sprawą pochodzącego ze Słowacji, ale piszącego po czesku poety Jana Kollára, a później znacznie rozszerzyła się wśród słowackich romantyków ${ }^{6}$. W kulturze słowackiej w ślad za Kollárem pojawiło się „uwielbienie” gór oraz identyfikowanie pejzażu z tożsamością narodową, co nie miało odpowiednika po stronie czeskiej, a nawet polskiej (badacz twierdzi, że „dla Polaków Tatry pozostały górami granicznymi, egzotycznymi i peryferyjnymi, a nie integralną częścią ojczyzny) ${ }^{7}$. Zwolennicy Macury, tacy jak Peter Zajac, uważają, że Tatry w koncepcji Kollára nie tylko rywalizowały w repertuarze ważnych pejzaży, ale całkowicie tłumiły znaczenie czeskich gór, mówiąc nawet wprost o ,zderzeniu dwóch" narodowo-przyrodniczych systemów tematycznych ${ }^{8}$. Ani jednak Zajac, ani Macura nie dają konkretnych dowodów na rzecz takiej tezy i sprawie trzeba raz jeszcze przyjrzeć się szczegółowo. Jest bowiem oczywiste, że dane ujęcia mogły się pojawiać w różnych typach tekstów i zasoby materiału mogły być nieograniczone. Dla potrzeb niniejszego studium wybraliśmy więc dwa obszary, w których przedstawienia były bardzo częste, a także reprezentowały prestiżową produkcję swoich czasów, która rozwijała aktualne tendencje literackie.

Jaka była wzajemna proporcja ówczesnych wyobrażeń o Karkonoszach i Tatrach oraz jak zostały one semantycznie spełnione, można łatwo zweryfikować na materiale poezji czeskiej. Dysponujemy Czeską Biblioteką Elektroniczną, czyli bazą danych wszystkich czeskich produkcji poetyckich napisanych i wydanych książkowo w latach 1770-1945, która umożliwia wyszukiwanie pełnotekstowe. Uzyskane wyniki (poprzez proste wpisanie słów Karkonosze, Tatry oraz ich

${ }^{6}$ V. Macura, Znamení zrodu..., s. 185-186.

7 Ibidem, s. 186. Jest to na pewno teza, na temat której można by długo dyskutować z polskimi badaczami.

${ }^{8}$ Tu w rozumieniu toposu zob. P. Zajac, L. Schmarcová, Slovenský romantizmus: synopticko-pulzačný model kultúrneho javu, Brno 2019, s. 37. Por. też J. Kolbuszewski, Tatry w literaturze polskiej, Krakow 1982; idem, Literatura i Tatry. Studia i szkice, Zakopane 2016. 
wariantów morfologicznych i słowotwórczych) pokazują, że Karkonosze były wykorzystywane 45 razy w latach $1790-1890$ w 30 zbiorach, Tatry reprezentowane zaś przez 162 wystąpienia w 70 zbiorach. W obu przypadkach słowa te pojawiają się bezpośrednio w ty tułach wierszy, czasem nawet w samych zbiorach, jednak Tatry zdecydowanie dominują (w latach czterdziestych i ponownie w siedemdziesiątych i osiemdziesiątych XIX stulecia) ${ }^{9}$. Wyniki te potwierdzałyby tezę Macury, że Tatry miały dominującą pozycję w literaturze czeskiej. Można jednak dodać, że tak nie było w całym tym obserwowanym okresie. Karkonosze są tematyzowane w kilku tekstach z lat 1810-1820, natomiast Tatry, z wyjątkiem kilku wzmianek ${ }^{10}$, pojawiają się dopiero w latach 1821 i 1824, zaś na początku powiązane są one tylko z Córą stawy (Slavy dcera) Kollára ${ }^{11}$.

Istotne różnice można prześledzić, skupiając się na znaczeniach, które niosły obie reprezentacje. W ten sposób dowiadujemy się, że między pierwszą a drugą dekadą XIX wieku Karkonosze były często przedstawiane jako pozbawione znamion mogących świadczyć, że są to góry „czeskie”, a ich koncepcja była dość zróżnicowana. W jednej z części obszernego poematu Wzniostość natury (Vznešenost prírody, 1813, 1819) Milota Zdirad Polák utożsamił Karkonosze z obrazem pięknej i tajemniczej przyrody, w której odbija się odwieczny cykl sił twórczych i destrukcyjnych wraz z wielkością Boga. Dla innego autora, Václava Klimenta Klicpery, w balladzie Chatka w Karkonoszach (Krkonošská kleč) czeskie góry są tylko atrakcyjnym miejscem, okropną przestrzenią zamieszkaną przez duchy, zwłaszcza przez Krakonosza. Koncepcja Karkonoszy jako części terytorium ojczyzny w ujęciu patriotycznie nastawionych intelektualistów pojawia się wyjątkowo. Znamienne jest wyrażone w odzie Do języka czeskiego (1795) Antonina Jaroslava Puchmajera życzenie, by Karkonosze przyjęły Czecha choćby jako swego ,giermka”, czyli nie w kontekście władcy, ale rycerza-sługi.

Karkonosze zaczęto interpretować jako część czeskiej ojczyzny dopiero w latach trzydziestych XIX wieku, kiedy to sposób semantycznego nacechowania zawęził się do pewnego rodzaju umownych kliszy. Karkonosze są tu pojmowane przede wszystkim jako „krawędź, kres ojczyzny, o tyle mający wielkie znaczenie, że tworzy zaporę obronną, nie do pokonania przez wrogów"12. Funkcję tę przypisuje się zresztą całości czeskich gór, czego przykładem jest wiersz Góry (Hory, 1839) ze zbioru Ojczyzna (Vlasta), którego autorem jest Karel Alois Vinařický: „Czechy są otoczone murami gór, których bastiony zwrócone są na cztery świata strony" "13. Wymienione są Karkonosze, Szumawa, Rudawy

9 Na przykład zbiory: Vítězslav Hálek Děvče z Tater; Otakar Mokrý Báj Tater; Adolf Heyduk Od Tater a Dunaje; Irma Geisslová Z Podkrkonoší.

10 Na przykład u Bohuslava Tablica (Poezie), a także wierszach Pavla Jozefa Šafárika, drukowanych w czasopiśmie „Prvotiny pěkných umění”.

11 Tatry pojawiają się u Kollára w Básních z roku 1821, w duchu erotycznych zabaw liryki anakreontycznej.

12 Pierwsze przejawy takiego pojmowania pojawiają się w latach dwudziestych XX wieku, np. w wierszu Baláda Josefa Krasoslava Chmelenského czy Krkonošské hory Josefa Mirovíta Krála.

13 K.A. Vinařický, Vlast. Skládání Karla Vinařického, Praha 1863, s. 2. 
i małe Góry Zdziarskie - z zaznaczeniem, że przejście udostępnią one tylko „braciom ze Wschodu”"14. Oczywista wizualnie forma geomorfologiczna Czech (geolodzy czescy twierdzą, że Czechy są niczym więcej jak „dziurą” po uderzeniu meteorytu) ${ }^{15}$ spełniła $\mathrm{w}$ ten sposób pożądane w skali kraju założenia, pojęcie „górskiej ściany” głęboko zadomowiło się w czeskim słowniku narodowym nie tylko w XIX, ale także XX wieku. Jak już wspomniano, Tatry weszły do czeskiej poezji za sprawą Jana Kollára i jego poematu Córa sławy. Autor stworzył w tym dziele obraz dawnego słowiańskiego imperium — regionu słowiańskiego, którego podstawowe cechy przedstawia w Przedśpiewie ${ }^{16}$. Biorąc pod uwagę, że jest to emblematyczny tekst romantyczny, nie dziwi fakt, że „słowiańska ojczyzna” zostaje wprowadzona na scenę przez emocjonalnie nacechowanego pielgrzyma, traumatyzowanego przez rozziew między chwalebną słowiańską przeszłością a obecnym nieszczęśliwym stanem. Ta szeroko pojmowana ojczyzna w naturalny sposób zmusiła poetę do ekspansji geograficznej i jednocześnie poszukiwania nowego centrum mitologicznego ${ }^{17}$. Rolę Caput Regni w miejsce Pragi Kollár oddał neutralnym semantycznie, ale centralnie usytuowanym Tatrom.

W ten sposób w rozumowaniu Kollára Czesi poszerzają swoją tożsamość, stają się Słowianami, „synami Tatr”, Tatry zaś są ich „kołyską i trumną”18. Uzasadnia tę koncepcję przeniesienie kategorii Czecha-Słowianina ze sfery kultury do przestrzeni naturalnej, ucywilizowanej tylko w ograniczonym zakresie. Stąd aspiruje on do czystości moralnej, niewinności i innych pozytywnych znaczeń, które przyniosły ze sobą idee pierwotnych cywilizacji w koncepcjach Jana Jakuba Rousseau. Kollár jest także tym, który postrzega Tatry jako przestrzeń świętą — są dla niego świątynią.

Mimo że Kollár był na początku lat dwudziestych XIX wieku jedynym autorem podejmującym problematykę tatrzańską, robił to w sposób bardzo przekonujący. Od lat trzydziestych jego sposób interpretowania Tatr stał się powszechnie przyjętą konwencją, która zajęła w poezji bardzo ważne miejsce. W poezji tego okresu pojawiają się tendencja do stereotypizacji motywów spopularyzowanych

14 Ibidem, s. 3.

15 V. Cílek, Krajiny vnitřni a vnějši: texty o paměti krajiny, smysluplném bobrovi, areálu jablkového štrúdlu a také o tom, proč lezeme na rozhlednu, Praha 2005.

16 Przykłady zob. Česká elektronická knihovna, databáze Ústavu pro českou literaturu AV ČR. Př́stup: http://www.ucl.cas.cz/cs/internetove-zdroje (dostęp: 15.07.2021).

17 Peter Macho dowodzi, że w pismach Kollára Tatry nabierały tego znaczenia stopniowo; w swoich tekstach publicystycznych, w przeciwieństwie do poetyckich, poeta myśli o Tatrach w sposób całkowicie neutralny; są one jedynie pojęciem geograficznym, a z punktu widzenia osadnictwa słowiańskiego lub słowackiego - raczej peryferiami, granicą. Zob. P. Macho, Od pravlasti ku koliske. Od Karpat ku Tatrám. Mýtus slovanského stredu v kontexte vývoja slovenskej národnej identity a ideológie, [w:] Z. Hojda, Slavme slavně slávu Slávóv slavných: slovanství a česká kultura 19. století: sborník přispěvki z 25. ročníku sympozia k problematice 19. století, red. M. Ottlová, R. Prahl, Praha 2006, s. 246.

18 Zob. „A tu leży ziemia ta przed okiem moim smutnie łzawym / niegdyś kolebka, a dziś trumna mego narodu / Nie depcz, to są święte miejsca” (J. Kollár, Slávy dcera, Praha 1971, s. 9). 
przez Córę sławy ${ }^{19}$. Jednym z nich było spojrzenie z wysokości Tatr — „ołtarza Słowian" - na utraconą w przeszłości wielkość, ale i nową wspaniałą przyszłość już zmierzającą do ojczyzny słowiańskiej ${ }^{20}$.

O silnym oddziaływaniu tego motywu świadczą nie tylko jego powtórzenia, ale także inne modyfikacje (na przyklad w wierszu Eliški Krásnohorskiej Córki Tatr odczuwają bolesny upadek chwalebnej przeszłości i z niecierpliwością oczekują szczęśliwszej przyszłości). W Cygańskich melodiach Vítězslava Hálka (Słowaka pochodzenia romskiego) jawią się one jako Słowianki.

Karkonosze w latach czterdziestych XIX wieku nie zniknęły z horyzontu czeskich poetów na skutek ekspansji Tatr (jest to sytuacja nieco późniejsza). Wręcz przeciwnie, istnieje tendencja do pewnego połączenia dwóch prestiżowych reprezentacji geograficznych. Świadczy o tym chociażby utwór następcy Kollára Jana Erazma Vocela - Labirynt stawy (1843), wariacja na temat Fausta Goethego. Akcja jego dzieła zaczyna się na szczycie Śnieżki, gdzie spotykamy młodego rozdartego Jana, który zatracił sens życia, nie wierzy w odrodzenie swojego narodu i myśli o samobójstwie. Ukazuje mu się zły duch ofiarowujący różne przyjemności i zabiera go w podróż przez teraźniejszość i przeszłość (według jego osądu nieistniejącej) ojczyzny słowiańskiej. Jednym z przystanków są Tatry, skąd widać całą „słowiańską ziemię zniewoloną we mgłach" ${ }^{21}$. Naruszenie stereotypu pojawia się rzadko: takim buntownikiem jest chyba tylko Karel Sabina, który na szczycie Karkonoszy umieszcza Słowianina „z wyżyn spoglądającego na swą ojczyznę"22.

O tym, że w latach trzydziestych i czterdziestych XIX wieku doszło do pewnej rywalizacji (słowo używane przez Petera Zajaca jest tu, moim zdaniem, zbyt ostre) dwóch kluczowych przedstawień, mitologii geograficznej i współczesnej kultury czeskiej, może świadczyć odmienne spektrum literackie - podróże (relacje z podróży). Świadczą one zarówno o rosnącym zainteresowaniu tymi pasmami górskimi, jak i pogłębiającym się szacunku dla ich literackiego wizerunku, który kształtuje się w poezji. Rozkład czasowy obu przedstawień odpowiada sytuacji w poezji. W latach 1810-1820, a nawet w połowie lat trzydziestych w literaturze czeskiej całkowicie dominowały opisy wycieczek w Karkonosze, ale od kolejnej dekady pojawiają się ich tatrzańskie odpowiedniki i ich liczba stopniowo rośnie. O tym, że podróże w Tatry dorównywały pod względem ilości

19 Dany motyw uwidacznia się także w dziełach niebeletrystycznych, szczególnie u słowackich romantyków. Jozef Miloslav Hurban w Slovensko a jeho život literárny (1847) pisze: „Tatry są kolebką i świętym ołtarzem Słowian”, ale u Hurbana, w przeciwieństwie od Kollára, Tary stają się istotą Słowacji: „W skamieniałym, litym masywie Tatr” patriotycznej, narodowej świadomości. Widzi on „wcieloną ideę Słowacji”, a spojrzenie na ich potężne szczyty „budzi w słowackiej duszy tajemne uczucia" narodowej i patriotycznej świadomości. Por. J.M. Hurban, Slovensko a jeho život literárny, [w:] idem, Dielo II, Bratislava 1983, s. 22.

20 W charakterystyczny sposób dzieje się to w almanachach „Ruch” (t. 2-3) (na przykład Bohuslav Čermák: Na Tater štitě, Karel Kálal: Z Tater).

21 J.E. Vocel, Labyrint slávy, Praha 1846, s. 167.

22 K. Sabina, Slovan, „Hronka” 1, 1837, nr 2, s. 105. 
karkonoskim, podczas gdy te pierwsze już całkowicie zdominowały poezję, może świadczyć fakt, że relacje podróżnicze opierają się zazwyczaj na autentycznej trasie, a czeskie góry były bardziej dostępne ${ }^{23}$.

Kluczowe jest jednak ustalenie znaczeń, które te dwie reprezentacje łączyły i które - jak pokazują reportaże podróżnicze — stały się w latach czterdziestych ogólnie przyjętą konwencją literacką. Już w pierwszych karkonoskich dziennikach podróżniczych, takich jak Josefa Myslimíra Ludvíka Myslimír, podróżujący po Karkonoszach (1824), różnorodność górskiej przyrody jest jedynie celebrowana i — na wzór Wzniostości przyrody Poláka - wyobrażana różnorodna sceneria krajobrazowa, którą Ludvík uchwycił, apoteozując ją prozą i wierszem. Nawet w latach czterdziestych naturalne krajobrazy są nadal najbardziej atrakcyjnym zjawiskiem, jakie można zobaczyć w górach, a także są specjalnie zlokalizowane. Václav Frič uważa wejście na Śnieżkę, widok na burzliwy wodospad i dzikie Śnieżne Kotły za kanoniczne motywy węrówki, jednocześnie jednak Karkonosze są konsekwentnie przedstawiane jako najdalsza granica Królestwa Czeskiego. Karkonoscy podróżnicy Josef Václav Frič i Václav Reischel wędrują z Pragi do granic „ojczyzny”, za którą rozciągają się „inne krajobrazy” ${ }^{24}$. Majestatyczne szczyty górskie, „obrazy odwiecznej trwałości i siły” 25 stanowią granicę między przestrzenią swoją a obcą. Egzaltacja narodowa jest wówczas na tym pograniczu nieobecna, zwracając się jedynie ku centrum, ku Pradze.

Odmiennie pojmowany jest obszar Tatr w kategoriach narodowych. Pierwszy topograficzny ich opis sięga połowy lat trzydziestych XIX wieku, a Tatry są w nim interpretowane w duchu Kollára jako „kolebka i być może pierwotna siedziba naszego narodu czechosłowackiego" i w nich „zachował się w czystej postaci narodowy charakter ${ }^{26}$ (autorem tego ujęcia był przyjaciel Kollára - Pavel Josef Šafařík). Tatrzańskie podróże z lat czterdziestych w pełni akceptują tę koncepcję. Jan Erazm Vocel, ceniony autor poezji patriotyczno-historycznej i opowiadań, we Fragmentach podróży z Tatr nad Morze Pólnocne (1843) ukazuje Tatry jako mistyczne centrum ojczyzny, ołtarz narodowy i świątynię, na łonie której zachowała się nietknięta przyroda. Pielgrzym Vocel przemierza góry nie po to, by udowadniać czytelnikom, że potrafi rozpoznać, docenić i dosłownie ukazać piękno przyrody, ale by potwierdzić niejako swą tożsamość narodową. Już na początku pielgrzym wspina się na wzgórze nad Kieżmarkiem, skąd obserwuje „majestatyczny obraz” wschodu słońca nad tatrzańskim krajobrazem² ${ }^{27}$. Gra świa-

${ }^{23}$ Były już do dyspozycji naukowe opisy Karkonoszy i przewodniki po nich, napisane wprawdzie po niemiecku, ale czytywane w Czechach: J.K.E. Hoser, Anleitung das Riesengebirge auf die zweckmässigste Art zu bereisen: Mit eine Karte von Junker, Wien 1805; K. Herloßsohn, Wanderungen durch das Riesengebirge und die Grafschaft Glatz: Mit 30 Stahlstichen, Leipzig 1840; idem, Wanderungen durch das Riesengebirge und die Grafschaft Glatz: Mit 30 Stahlstichen, Leipzig $1840 / 1841$.

24 J.V. Frič, Cesta přes Friedland na Krkonoše, „Poutník” 1, 1846, s. 120.

25 V.H. Reischel, Cesta na Sněžku, „Poutník” 2, 1847, s. 1.

26 P.J. Šafařík, Horalé, obyvatelé tatranští, „Světozor” 1, 1834, nr 19, s. 146-147.

27 J.E. Vocel, Výjimka z cesty od Tater moři, „Časopis českého Museum” 17, 1843, nr 4, s. 540. 
teł i cieni, zmiana barw, kompozycja kontrastujących elementów przyrody, którą obserwuje z najwyższego punktu pejzażu, uprzywilejowanego miejsca romantycznych tematów, prowadzi go do patriotycznej ekstazy, podnieconej modlitwy za naród słowiański: „Od tej chwili [...] ze wschodu, zachodu, północy i południa błagamy o dziennik prawdy i oświecenia dźwigu narodowego". Odtąd piękno krajobrazu jest konsekwentnie postrzegane nie jako ogólna materia estetyczna, ale wartość narodowa - górski krajobraz Tatr to przede wszystkim „brama do słowiańskiego raju"28.

Większy potencjał nacjonalizacji oznacza, że Tatry mogą (dopiero w latach czterdziestych XIX wieku) zyskać pewien priorytet nad Karkonoszami, co objawia się albo ich substytucją (Vocel wyraźniej zastępuje Karkonosze słowiańskim Beskidem lub Śnieżką pod Radhoszczem), albo wyraźną przewagę. W Notatkach podróżnika na Stowację Viléma Dušana Lambla znajduje się bezpośrednie porównanie Tatr i Karkonoszy, a efektem jest stwierdzenie dewaluacji Karkonoszy, której sprawcami są Niemcy i rozwijająca się turystyka masowa. Według podróżnika w górach tłoczą się przybysze „,z wielkich miast”, którzy „,przenoszą się tu ze swoimi przywarami" ${ }^{29}$. Z ich powodu miejscowi Niemcy zamieniają Karkonosze z „tej wspaniałej świątyni przyrody” w prawdziwą ,jaskinię zbójców”, w której wędrowiec musi wydać pieniądze nawet na uruchomienie wodospadu (strumień jest blokowany przez miejscowych i uruchamiany tylko za opłatą) ${ }^{30}$. W przeciwieństwie do Tatr nie ma tu już miejsca na uczucia patriotyczne.

Wczesna literatura podróżnicza i poezja pokazują, że obraz obu pasm górskich uległ pewnej mitologizacji. Jednolicie pojmowano je jako przestrzeń sakralną, porównywaną do ołtarza, świątyni, katedry. W przypadku Karkonoszy jest to jednak przede wszystkim nieoznaczona narodowo świątynia „wzniosłej, majestatycznej przyrody", podczas gdy przyroda tatrzańska jest zawsze obciążona symboliką narodową. Na szczyt Karkonoszy jako pierwsi docierają miłośnicy przyrody, a nawet turyści szukający przyjemności i rozrywki, ale Tatry są zawsze miejscem narodowych aspiracji. Podsumowując, można stwierdzić, że w przypadku karkonoskich i tatrzańskich travelogues były to zazwyczaj opisy autentycznych podróży, a ich literacka reprezentacja zawiera szereg indywidualnych przeżyć i zdarzeń. Niemniej jednak większość ówczesnych pisarzy-podróżników dostosowała się do panujących konwencji literackich i oczekiwań czytelników: w rezultacie przedstawienia Karkonoszy i Tatr były stale stereotypizowane, co doprowadziło aż do pewnej ich idealizacji (Karkonosze jako idealna przestrzeń majestatycznej przyrody — Tatry jako idealna przestrzeń narodowa). Jednocześnie przedstawienia te pokazują nam, że to, co zyskało etykietę „naszej przestrzeni narodowej”, przeszło znaczną ewolucję i niekoniecznie kończyło się w granicach terytorium czeskiego.

\section{Z języka czeskiego przełożyt} Jacek Kolbuszewski

\footnotetext{
28 Ibidem, s. 570.

29 V.D. Lambl, Zápisky cestujicího po Slovensku, „Poutník” 2, 1847, s. 104.

30 Ibidem.
} 